\title{
Pitting Corrosion of Some Stainless Steel Alloys Preoxidized at Different Conditions
}

\author{
S.S. Mahmoud" and M.M. Ahmed \\ ${ }^{a}$ Chemistry Department, University College of Girls for Arts, Science and Education, \\ Ain Shams University, Heliopolis, Cairo, Egypt
}

Received 8 February 2006; accepted 30 April 2007

\begin{abstract}
The pitting corrosion of some stainless steel alloys (preoxidized at different conditions) in $3.5 \% \mathrm{NaCl}$ solution was studied. The alloys are: one ferritic $(15.05 \% \mathrm{Cr})$ (alloy1) and two austenitic stainless steel alloys $(17.9 \% \mathrm{Cr}, 7.08 \% \mathrm{Ni})$ (alloy 2$)$ and $(20.45 \% \mathrm{Cr}, 8.3 \%$ Ni) (alloy3). Potentiodynamic anodic polarization and galvanic current-time measurements were used in these investigations. The susceptibility of the alloys to pitting corrosion decreases with the increase of chromium content of the alloy and with the presence of nickel in the alloy. The preoxidation of the alloys in different media improves their resistance to pitting corrosion in $\mathrm{NaCl}$ solution. The resistance to pitting corrosion for the investigated alloy increases according to the order: no oxidation < oxidation in air $<$ oxidation in molten alkali nitrates $<$ oxidation in molten alkali carbonates. This resistance to pitting corrosion may be due to the formation of a protective oxide film on the alloys' surface. The composition of this film greatly depends on the chemical composition of the alloy, on the condition of the preoxidation process, and on the temperature.
\end{abstract}

Keywords: stainless steel alloys, pitting corrosion, molten alkali nitrates, molten alkali carbonates.

\section{Introduction}

The corrosion resistance of stainless steel is due to a $20-40 \AA$ passive protective film which consists mainly of $\mathrm{Cr}_{2} \mathrm{O}_{3}$. It has been reported that the high temperature oxide film produced during soldering and stress relieving operations has reduced localized corrosion resistance. Bianchi et al. [1] observed that there is a close relationship between susceptibility to pitting and electronic properties of the oxide film produced at lower temperature. The n-type semiconductor oxides are more susceptible to pitting than their p- type counter parts. However,

\footnotetext{
* Corresponding author. E-mail address: : drsohairr@hotmail.com
} 
Kearns [2] attributed the higher pitting susceptibility of oxides formed at higher temperatures to chromium depletion in the alloy substrate beneath the oxide. Rastogi et al [3] attributed the increased pitting susceptibility of oxidized stainless steel specimens at $500{ }^{\circ} \mathrm{C}$ to the change of chemical composition of the oxide film i.e. lowering of $\mathrm{Cr} / \mathrm{Fe}$ concentration ratio.

Pitting corrosion can be minimized by means of many ways. One of these ways is the modification of the metallic surface by its oxidation and formation of passive oxide films. These films can be formed by oxidation in air at high temperatures and /or in molten oxyanion salts (such as molten alkali nitrates and alkali carbonates).

In this paper the effect of composition of stainless steel alloys and the conditions of preoxidation process on the pitting corrosion of some stainless steel alloys were studied. The stainless steel alloys are: one ferritic and two austenitic stainless steel alloys. The preoxidation was performed in air at high temperatures, in molten alkali nitrates and in molten alkali carbonates. After the preoxidation of the alloys their pitting corrosion behaviour in $3.5 \% \mathrm{NaCl}$ was tested.

\section{Experimental}

Three specimens of the two types of stainless steel have been prepared and used in these investigations. The first one is from ferritic steel $(15.05 \% \mathrm{Cr}$ ) (alloy1). The other two are from austenitic steel, one with $(17.9 \% \mathrm{Cr}+7.08 \% \mathrm{Ni})$ (alloy2) and the other $(20.45 \% \mathrm{Cr}+8.3 \% \mathrm{Ni})$ (alloy3). The samples were treated at $1050{ }^{\circ} \mathrm{C}$ for 15 minutes in the presence of $\mathrm{N}_{2}$ gas followed by rapid quenching in water to prevent any sensation to intercrystalline corrosion, and all carbides have then gone into solution [4]. After this treatment the samples were pickled in a mixture solution of $100 \mathrm{~mL}$ of concentrated $\mathrm{HCl}, 100 \mathrm{~mL}$ of distilled water and $10 \mathrm{~mL}$ of concentrated $\mathrm{HNO}_{3}$ at $60{ }^{\circ} \mathrm{C}$ for 20 minutes. The samples were cleaned, washed thoroughly with distilled water and dried.

The samples were treated at temperatures of 500 and $550{ }^{\circ} \mathrm{C}$ in each of the following media: 1-in air, 2- in molten nitrate and 3- in molten carbonate.

In air the samples were heated at temperatures of 500 and $550^{\circ} \mathrm{C}$ for one hour and cooled to room temperature.

The $\mathrm{NaNO}_{3}-\mathrm{KNO}_{3}$ eutectic (AR grade, molar ratio 50:50; melting point of 225 ${ }^{\circ} \mathrm{C}$ ) was prepared and dried as previously described [5-7]. Experiments of sample treatment were carried out as previously described [5-7]. The experiments of sample treatment in nitrate melt at temperatures of 500 and $550{ }^{\circ} \mathrm{C}$ were prolonged till reaching the steady- state potential for the samples under opencircuit conditions.

The ternary $\mathrm{Li}_{2} \mathrm{CO}_{3}-\mathrm{Na}_{2} \mathrm{CO}_{3}-\mathrm{K}_{2} \mathrm{CrO}_{3}$ (43.5: $31.5: 25$ mole\%, respectively) mixture was prepared and dried as previously recommended [8-10]. This mixture of alkali carbonates is of interest in oxidation studies because of its low melting point $\left(397{ }^{\circ} \mathrm{C}\right)$ and good electrical properties. The experiments of sample treatment in molten carbonate were carried out as previously described [8-10]. These experiments were carried out at temperatures of 500 and $550{ }^{\circ} \mathrm{C}$ till reaching the steady-state potential under the open-circuit conditions. 
The pitting corrosion tests in $3.5 \% \mathrm{NaCl}$ were carried out on the samples which are: without oxidation, oxidized in air, oxidized in nitrate melt, oxidized in carbonate melt. The techniques of measurements used in these tests were: ipotentiodynamic anodic polarization with scan rate of $1 \mathrm{mV} / \mathrm{sec}$., ii- galvanic current-time. A platinum electrode and a saturated calomel electrode were used as auxiliary and reference, respectively. The anodic polarization measurements were carried with a Wenking potentiostat (model POS 73). The galvanic current was measured on digital multimeter(model 1008,Kyoritsu Electrical Instruments work, LTD Japan).

\section{Results and discussion}

Fig. 1 represents the potentiodynamic anodic polarization curves for the investigated alloys $(1,2,3)$ immersed in $3.5 \% \mathrm{NaCl}$ solution. It is clear from these plots that no active dissolution of oxidation peak was observed during the anodic scan. The current flowing along the passive region increases suddenly and markedly at some definite potentials denoting the initiation of visible pits on the electrode surface. These potentials are called pitting potentials, $\mathrm{E}_{\mathrm{pit}}$; the value of $\mathrm{E}_{\text {pit }}$ was deduced from the plots of Fig. 1 for the alloys $(1,2,3)$ and listed in table 1. The value of $\mathrm{E}_{\mathrm{pit}}$ shifts to the more positive direction according to the order: $1 \rightarrow 2 \rightarrow 3$.

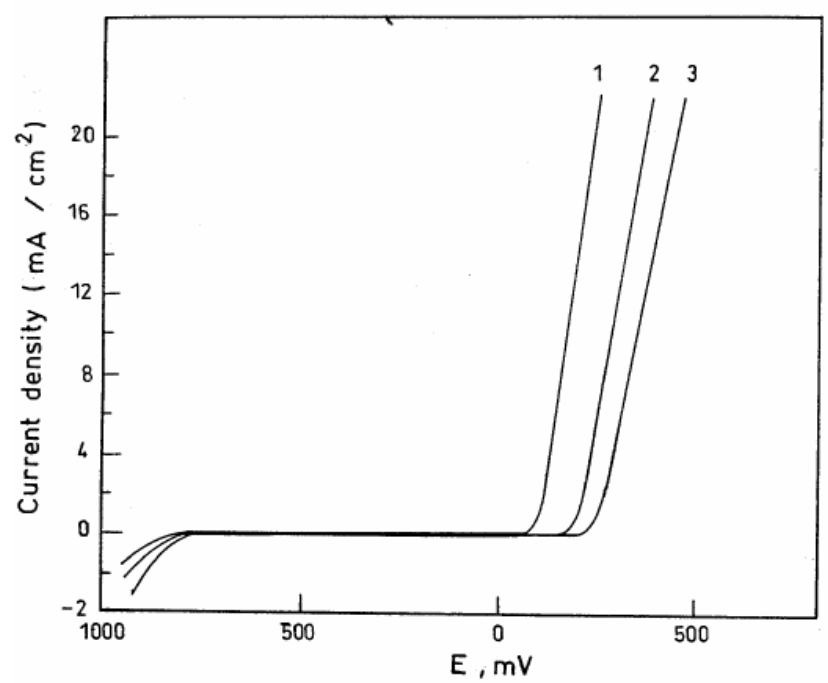

Figure 1. Potentiodynamic anodic polarization curves of the stainless steel alloys in 3.5 $\% \mathrm{NaCl}$ solution: 1- alloy 1, 2- alloy 2, 3- alloy 3 .

Fig. 2 represents the potentiodynamic anodic polarization curves for the alloys $(1,2,3)$ preoxidized in air at $500{ }^{\circ} \mathrm{C}$ and immersed in $3.5 \% \mathrm{NaCl}$ solution. Similar curves are obtained for the alloys preoxidized at $550{ }^{\circ} \mathrm{C}$, but not shown. The values of $\mathrm{E}_{\mathrm{pit}}$ are deduced from the plots of Fig. 2 and similar ones and listed in table 1. It is clear from these results that the values of $\mathrm{E}_{\mathrm{pit}}$ for the alloys preoxidized at $550{ }^{\circ} \mathrm{C}$ are more positive than for preoxidation at $500{ }^{\circ} \mathrm{C}$. Also, the value of $\mathrm{E}_{\mathrm{pit}}$ shifts to the more positive direction according to the order: $1 \rightarrow 2 \rightarrow 3$. 
Table 1. Values of pitting potential, $\mathrm{E}_{\mathrm{pit}}$, for the alloys in $3.5 \% \mathrm{NaCl}$ solution at different conditions.

\begin{tabular}{|c|c|c|c|c|c|c|c|}
\hline \multirow{3}{*}{ Alloy } & \multicolumn{7}{|c|}{$\mathrm{E}_{\mathrm{pit}}(\mathrm{mV})$} \\
\hline & \multirow{2}{*}{$\begin{array}{c}\text { No } \\
\text { oxidation }\end{array}$} & \multicolumn{2}{|c|}{ Oxidation in air } & \multicolumn{2}{|c|}{$\begin{array}{l}\text { Oxidation in } \\
\text { nitrate melt }\end{array}$} & \multicolumn{2}{|c|}{$\begin{array}{l}\text { Oxidation in } \\
\text { carbonate melt }\end{array}$} \\
\hline & & $500{ }^{\circ} \mathrm{C}$ & $550^{\circ} \mathrm{C}$ & $500^{\circ} \mathrm{C}$ & $500^{\circ} \mathrm{C}$ & $500^{\circ} \mathrm{C}$ & $550^{\circ} \mathrm{C}$ \\
\hline 1 & 50 & 250 & 300 & 400 & 460 & 600 & 650 \\
\hline 2 & 150 & 350 & 390 & 500 & 580 & 720 & 790 \\
\hline 3 & 200 & 400 & 440 & 560 & 620 & 820 & 900 \\
\hline
\end{tabular}

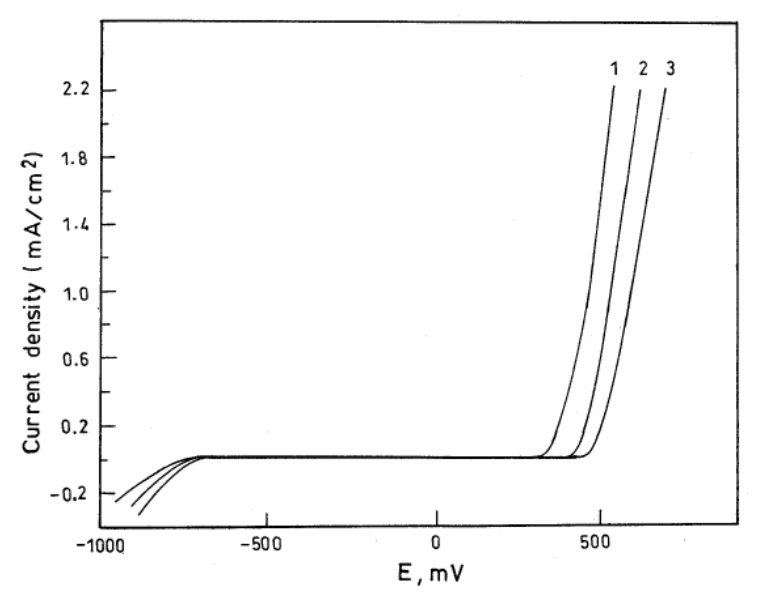

Figure 2. Potentiodynamic anodic polarization curves of the stainless steel alloys (preoxidized in air at $500{ }^{\circ} \mathrm{C}$ ) in $3.5 \% \mathrm{NaCl}$ solution: 1- alloy 1, 2- alloy 2, 3- alloy 3.

Fig. 3 represents the potentiodynamic anodic polarization curves for the investigated alloys $(1,2,3)$, preoxidized in nitrate melt at $500{ }^{\circ} \mathrm{C}$, immersed in $3.5 \% \mathrm{NaCl}$ solution. Similar curves are obtained for the alloys preoxidized at 550 ${ }^{\circ} \mathrm{C}$, but not shown. From the plots of Fig. 3 and similar ones the values of $\mathrm{E}_{\text {pit }}$ are deduced for the three alloys and listed in table 1 . These results indicate that the values of $\mathrm{E}_{\mathrm{pit}}$ for the alloys preoxidized at $550{ }^{\circ} \mathrm{C}$ are more positive than for the preoxidation at $500{ }^{\circ} \mathrm{C}$. Also, the value of $\mathrm{E}_{\text {pit }}$ for the alloys shifts to the more positive direction according to the order: $1 \rightarrow 2 \rightarrow 3$.

Fig. 4 represents the potentiodynamic anodic polarization curves for the investigated alloys $(1,2,3)$ preoxidized in carbonate melt at $500{ }^{\circ} \mathrm{C}$, immersed in $3.5 \% \mathrm{NaCl}$ solution. Similar curves are obtained for the alloys preoxidized at 550 ${ }^{\circ} \mathrm{C}$ in carbonate melt, but not shown. From the plots of Fig. 4 and similar ones the values of $\mathrm{E}_{\mathrm{pit}}$ for the alloys are deduced and listed in table 1 . The obtained results indicate that the values of $\mathrm{E}_{\mathrm{pit}}$ for the alloys preoxidized at $550^{\circ} \mathrm{C}$ in carbonate 
melt are more positive than for the preoxidation at $500{ }^{\circ} \mathrm{C}$. Also, the value of $\mathrm{E}_{\text {pit }}$ for the investigated alloys shifts to the more positive direction according to the order: $1 \rightarrow 2 \rightarrow 3$.

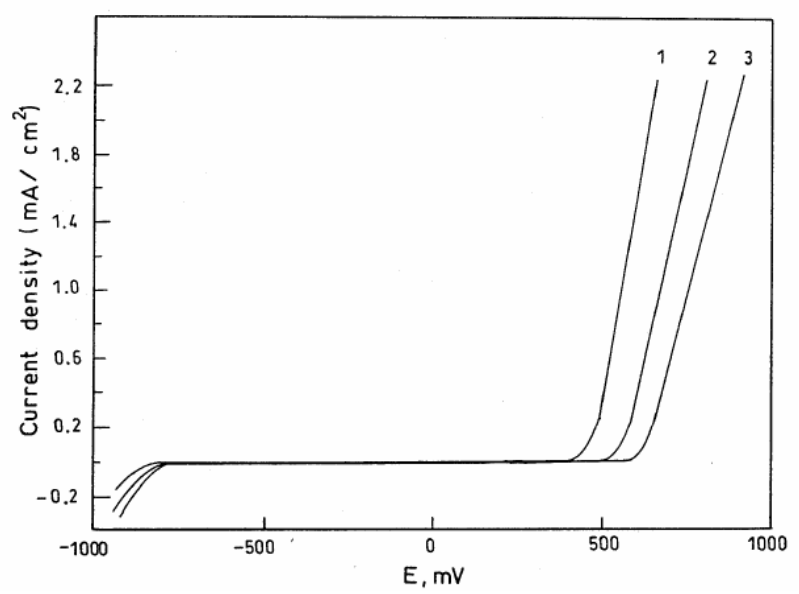

Figure 3. Potentiodynamic anodic polarization curves of the stainless steel alloys (preoxidized in molten alkali nitrate at $500{ }^{\circ} \mathrm{C}$ ) in $3.5 \% \mathrm{NaCl}$ solution: 1- alloy 1, 2alloy 2,3 - alloy 3 .

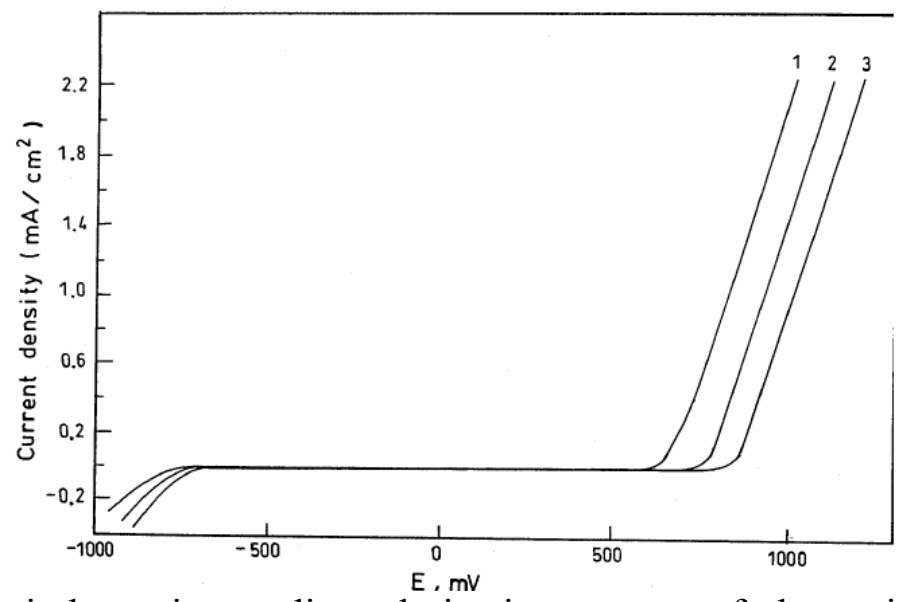

Figure 4. Potentiodynamic anodic polarization curves of the stainless steel alloys (preoxidized in molten alkali carbonate at $500{ }^{\circ} \mathrm{C}$ ) in $3.5 \% \mathrm{NaCl}$ solution: 1 - alloy 1, 2alloy 2, 3- alloy 3.

Fig. 5 shows a schematic presentation for the results of $\mathrm{E}_{\text {pit }}$ obtained for the alloys without oxidation and preoxidation in each of air, nitrate melt, carbonate melt at $500{ }^{\circ} \mathrm{C}$. Similar plots are obtained for the alloys preoxidized at $550{ }^{\circ} \mathrm{C}$, but not shown. The results of table 1 and the plots of Fig. 5 and similar ones indicate that the value of $\mathrm{E}_{\mathrm{pit}}$ for the investigated alloys shifts to the more positive direction according to the order: no oxidation $\rightarrow$ oxidation in air $\rightarrow$ oxidation in nitrate melt $\rightarrow$ oxidation in carbonate melt. Also, at the given conditions the values of $\mathrm{E}_{\text {pit }}$ for the alloys $(1,2,3)$ preoxidized at $550{ }^{\circ} \mathrm{C}$ are more positive than those preoxidized at $500{ }^{\circ} \mathrm{C}$. 


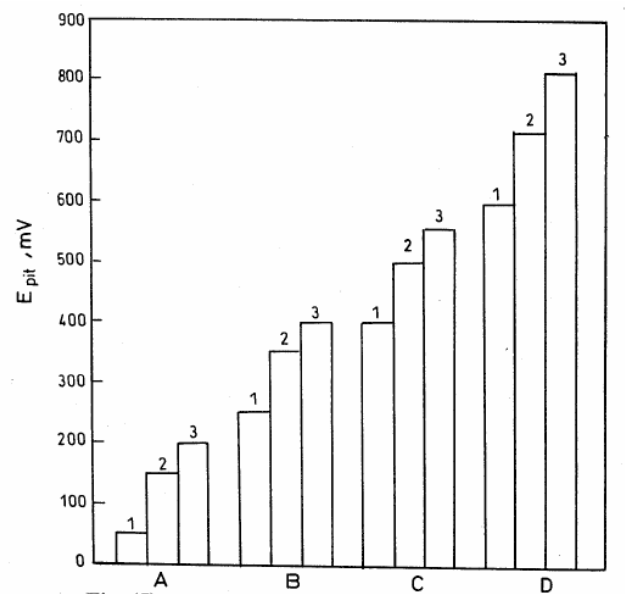

Figure 5. Pitting corrosion potential, $E_{\text {pit }}$, for the stainless steel alloys $(1,2$ and 3$)$ in 3.5 $\% \mathrm{NaCl}$ solution, at different conditions of treatment: A- no oxidation, B- oxidation in air, C- oxidation in molten alkali nitrates, D- oxidation in molten alkali carbonates.

Fig. 6 represents the variation of the galvanic current as a function of exposure time for the investigated alloys $(1,2,3)$ immersed in $3.5 \% \mathrm{NaCl}$ solution. These plots indicate that there is an induction period required for the initiation and propagation of the pitting corrosion on the surface of the electrode, as indicated by a sudden increase in the galvanic current and appearance of fluctuations on the curves. The value of the induction was deduced from the plots of Fig. 6 for each alloy and listed in table 2. It is clear form the obtained results that the value of the induction period greatly deqends on the type of the alloy and increases according to the order: $1<2<3$.

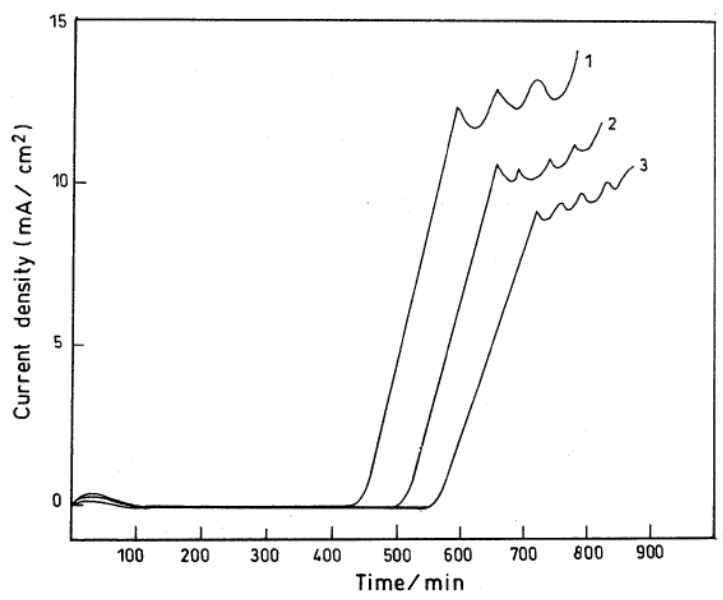

Figure 6. Galvanic current-time plots for the stainless steel alloys in $3.5 \% \mathrm{NaCl}$ solution: 1- alloy 1, 2- alloy 2, 3- alloy 3 .

Fig. 7 represents the variation of the galvanic as a function of exposure time for the alloys, preoxidized in air at $500{ }^{\circ} \mathrm{C}$, immersed in $3.5 \% \mathrm{NaCl}$ solution. Similar plots are obtained for the alloys preoxidized in air at $550{ }^{\circ} \mathrm{C}$, but not shown. The values of the induction period for the alloys were deduced from the plots of Fig. 
7 and similar ones and listed in table 2. It is found that the induction period for the investigated alloys increases according to the order: $1<2<3$.

Fig. 8 represents the variation of the galvanic current as a function of exposure time for the investigated alloys $(1,2,3)$ immersed in $3.5 \% \mathrm{NaCl}$ solution after their oxidation in the nitrate melt at a temperature of $500{ }^{\circ} \mathrm{C}$. Similar plots are obtained for the alloys $(1,2,3)$ preoxidized at $550{ }^{\circ} \mathrm{C}$, but not shown. The values of the induction period are deduced from the plots of Fig. 8 and similar ones and listed in table 2 . The obtained results indicate that the value of induction period increases according to the order: $1<2<3$.

Table 2. Values of induction period for the alloys in $3.5 \% \mathrm{NaCl}$ solution at different conditions.

\begin{tabular}{|c|c|c|c|c|c|c|c|}
\hline \multirow{2}{*}{ Alloy } & \multicolumn{6}{|c|}{ Induction period / min } \\
\cline { 2 - 8 } & \multirow{2}{*}{$\begin{array}{c}\text { No } \\
\text { oxidation }\end{array}$} & \multicolumn{2}{|c|}{ Oxidation in air } & \multicolumn{2}{c|}{$\begin{array}{c}\text { Oxidation in } \\
\text { nitrate melt }\end{array}$} & \multicolumn{2}{c|}{$\begin{array}{c}\text { Oxidation in } \\
\text { carbonate melt }\end{array}$} \\
\cline { 3 - 8 } & $500^{\circ} \mathrm{C}$ & $550^{\circ} \mathrm{C}$ & $500^{\circ} \mathrm{C}$ & $550^{\circ} \mathrm{C}$ & $500^{\circ} \mathrm{C}$ & $550^{\circ} \mathrm{C}$ \\
\hline 1 & 430 & 600 & 685 & 700 & 785 & 830 & 920 \\
\hline 2 & 500 & 680 & 760 & 780 & 860 & 930 & 1000 \\
\hline 3 & 550 & 730 & 820 & 830 & 920 & 990 & 1090 \\
\hline
\end{tabular}

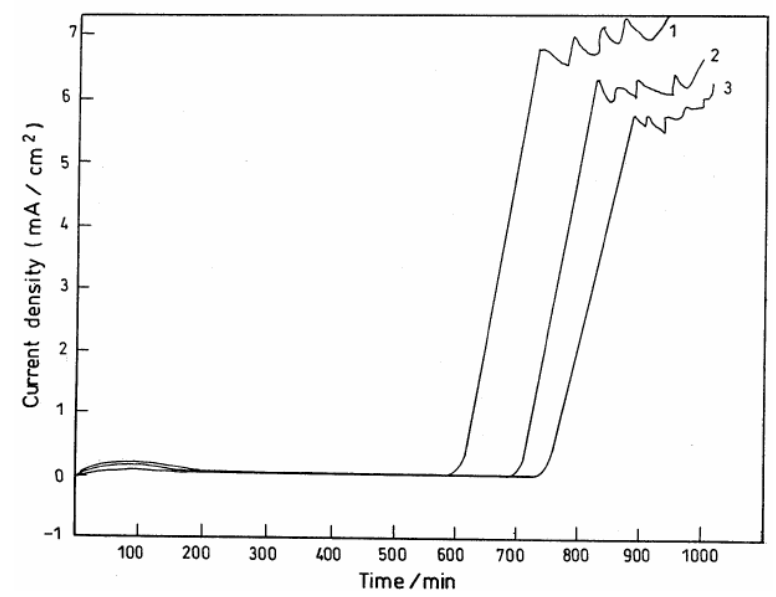

Figure 7. Galvanic current-time plots for the stainless steel alloys (preoxidized in air at $500{ }^{\circ} \mathrm{C}$ ) in $3.5 \% \mathrm{NaCl}$ solution: 1- alloy 1, 2- alloy 2, 3- alloy 3.

Fig. 9 represents the variation of the galvanic current as a function of exposure time for the investigated alloys $(1,2,3)$ immersed in $3.5 \% \mathrm{NaCl}$ solution after their oxidation in carbonate melt at a temperature of $500{ }^{\circ} \mathrm{C}$. Similar plots are 
obtained for the alloys $(1,2,3)$ preoxidized at $500{ }^{\circ} \mathrm{C}$, but not shown. The values of the induction period are deduced from the plots of Fig. 9 and similar ones and listed in table 2 . The obtained results indicate that the value of the induction period increases according to the order: $1<2<3$.

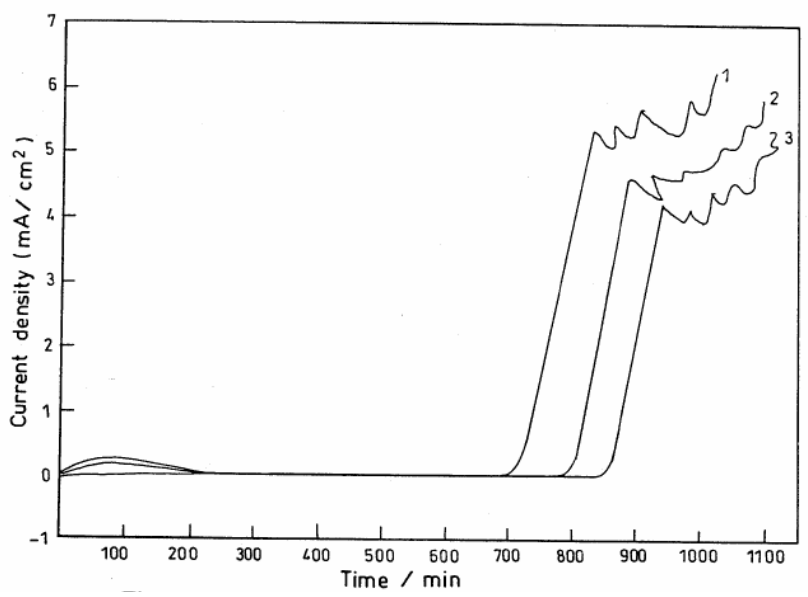

Figure 8. Galvanic current-time plots for the stainless steel alloys (preoxidized in molten alkali nitrates) in $3.5 \% \mathrm{NaCl}$ solution: 1- alloy 1, 2- alloy 2, 3- alloy 3.

Fig. 10 shows a schematic representation of the results of the induction period obtained for the alloys $(1,2,3)$ without oxidation and preoxidation at the temperature of $500{ }^{\circ} \mathrm{C}$ in air, molten nitrate and molten carbonate. Similar plots are obtained for the alloys $(1,2,3)$ preoxidized at $550{ }^{\circ} \mathrm{C}$,but not shown. The results listed in table 2 and the plots of Fig. 10 and similar ones indicate that the value of induction period increases according to the order: no oxidation < oxidation in air $<$ oxidation in nitrate melt $<$ oxidation in carbonate melt. Also at those conditions the value of induction period for the alloys $(1,2,3)$ preoxidized at $550{ }^{\circ} \mathrm{C}$ are longer than that for the alloys preoxidized at $500{ }^{\circ} \mathrm{C}$.

Pitting corrosion is a localized attack of metals and alloys which occurs as a result of the breakdown of the otherwise protective passive film on the metal surface. Many engineering metals and alloys such as stainless steel are useful due to the formation of passive oxide films. This passive state in damaged and pitting corrosion occurs when these alloys are polarized above some potentials in environments containing certain aggressive agents such as chloride. Pitting corrosion can be minimized by means of many ways. One of these ways is the the modification of the metallic surface by its oxidation and formation of passive oxide films. These films can be formed by oxidation in air at high temperature and/ or in molten oxyanion salts (such as molten nitrates and molten carbonates). Molten alkali nitrate eutectics are simple and convenient media for oxidation of metals and alloys because the oxide ion activity at temperature $>500 \mathrm{~K}$ is sufficiently high [11]. In molten nitrate the oxygen ions are originated by selfdissociation according to the equilibrium:

$$
\mathrm{NO}_{3}^{-} \rightleftharpoons \mathrm{NO}_{2}^{+}+\mathrm{O}^{2-}
$$




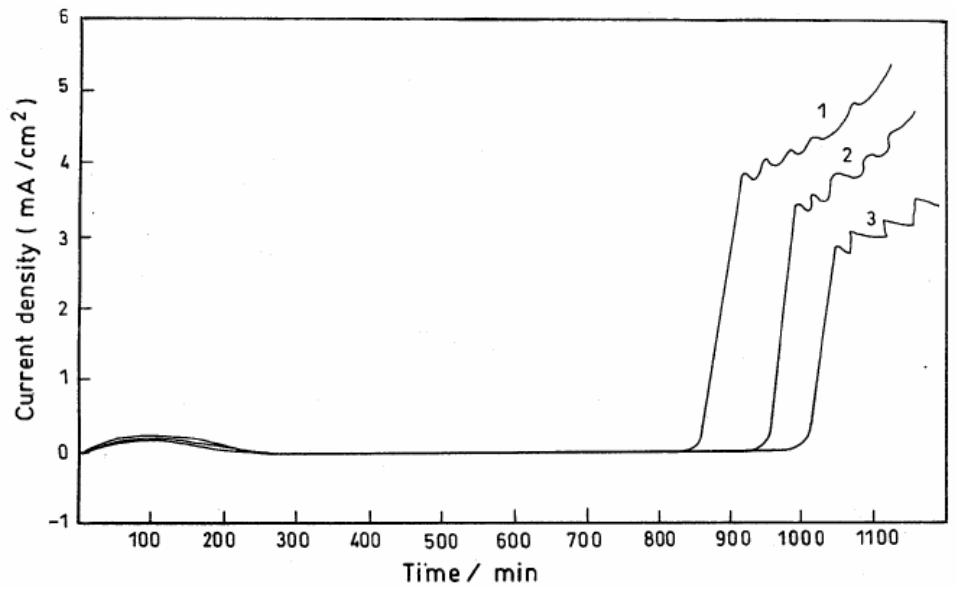

Figure 9. Galvanic current-time plots for the stainless steel alloys (preoxidized in molten alkali carbonates) in $3.5 \% \mathrm{NaCl}$ solution: 1- alloy 1, 2- alloy 2, 3- alloy 3.

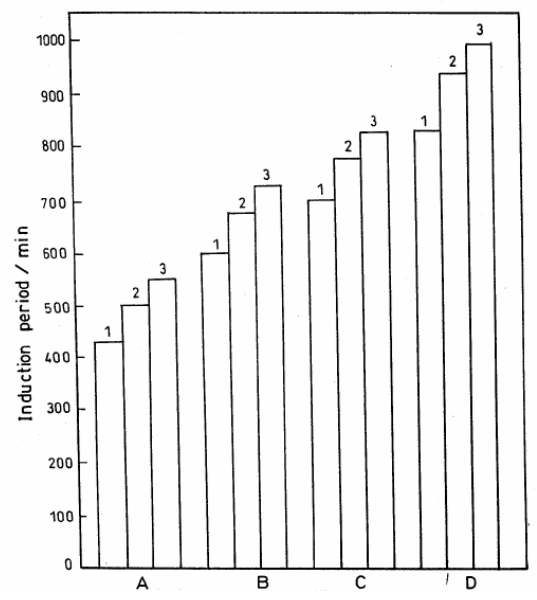

Figure 10. Induction period for the stainless steel alloys (1, 2 and 3$)$ in $3.5 \% \mathrm{NaCl}$ solution, at different conditions of treatment: A- no oxidation, B- oxidation in air, Coxidation in molten alkali nitrates, D- oxidation in molten alkali carbonates.

The concentration of oxygen ions can be calculated from the equilibrium constants. Marchiano and Arvia have worked out Pourbaix-type potential versus $\mathrm{pO}^{2-}\left(\mathrm{pO}^{2-}=-\log \left[\mathrm{O}^{2-}\right]\right)$ diagrams for molten nitrates and nitrites [12]. It is seen from these diagrams that the various cathodic reactions leading to the formation of oxygen ions occur at negative potential $-1.0 \mathrm{~V}$. It was found that the corrosion potential during the oxidation of the investigated stainless steel alloys $(1,2,3)$ in molten nitrate melt ranged from -1.10 to $-0.25 \mathrm{~V}$ depending on temperature [13]. Therefore the oxygen ions, $\mathrm{O}^{2-}$, and nitryl ions, $\mathrm{NO}_{2}^{+}$, play an important role in the oxidation process.

The reaction leading to the oxidation of these alloys thus:

$$
\begin{aligned}
& \mathrm{M} \rightleftharpoons \mathrm{M}^{\mathrm{n}+}+\mathrm{ne} \\
& \mathrm{M}^{\mathrm{n}+}+\mathrm{n} / 2 \mathrm{O}^{2-} \rightleftharpoons \mathrm{MO}_{\mathrm{n} / 2}
\end{aligned}
$$


while the cathodic reaction is:

$$
\mathrm{NO}_{2}^{+}+\mathrm{e} \rightleftharpoons \mathrm{NO}_{2}
$$

According to the postulates of electrochemical theory, the anodic processes may be metal dissolution and / or anodic barrier layer formation beside the oxidation of the solvent. Barrier layer may be formed by a dissolution-precipitation mechanism and/or a solid state mechanism.

The results of x-ray diffraction analysis [6] carried out on stainless steel alloys immersed in molten nitrate under open-circuit conditions indicate that the composition and percentage of different phases formed on the surface greatly depends on the type of the stainless steel alloy. For alloy (1) the phases formed are: $\mathrm{FeO}, \mathrm{Fe}_{3} \mathrm{O}_{4}, \mathrm{FeCr}_{2} \mathrm{O}_{4}$ spinel. While for alloys $(2,3)$ the phases formed are: $\mathrm{FeO}, \mathrm{Fe}_{3} \mathrm{O}_{4}, \mathrm{FeCr}_{2} \mathrm{O}_{4}, \mathrm{NiCr}_{2} \mathrm{O}_{4}$ and $\mathrm{NiFe}_{2} \mathrm{O}_{4}$ spinels.

In molten carbonate the oxide ions are originated by self-dissociation according to the equilibrium:

$$
\mathrm{CO}_{3}^{2-} \rightleftharpoons \mathrm{CO}_{2}+\mathrm{O}^{2-}
$$

this reaction is responsible for the presence of oxide ions in the carbonate melt . In Lux- Flood acid-base properties, $\mathrm{CO}_{2}$ is the acid and $\mathrm{O}^{2-}$ is the base. It can be assumed that the oxide ions, $\mathrm{O}^{2-}$, and carbonate ions, $\mathrm{CO}_{3}^{2-}$, play an important role in the oxidation process of the stainless steel alloys in the carbonate melt. Thus the reaction leading to the oxidation of different metals in the alloy may be represented by the following equations:

$$
\mathrm{M}+\mathrm{n} / 2 \mathrm{O}^{2-} \rightleftharpoons \mathrm{MO}_{\mathrm{n} / 2}+\mathrm{ne}
$$

and / or

$$
\mathrm{M}+\mathrm{n} / 2 \mathrm{CO}_{3}^{2-} \rightleftharpoons \mathrm{MO}_{\mathrm{n} / 2}+\mathrm{n} / 2 \mathrm{CO}_{2}+\mathrm{ne}
$$

in the case of carbonate melt and the investigated alloys $(1,2,3)$, it can be proposed, as in previous works $[8,14,15]$, that the oxidation and passivation of the alloys may proceed according to the following reactions:

$$
\begin{aligned}
\mathrm{Cr}+\mathrm{Li}^{+}+2 \mathrm{CO}_{3}^{2-} & \rightarrow \mathrm{LiCrO}_{2}+2 \mathrm{CO}_{2}+2 \mathrm{e} \\
\mathrm{Fe}+\mathrm{CO}_{3}^{2-} & \rightarrow \mathrm{FeO}_{\mathrm{ss}}+\mathrm{CO}_{2}+2 \mathrm{e} \\
\mathrm{Fe}+\mathrm{Li}^{+}+2 \mathrm{CO}_{3}^{2-} & \rightarrow \mathrm{LiFeO}_{2(\mathrm{ss})}+2 \mathrm{CO}_{2}+3 \mathrm{e}
\end{aligned}
$$

A cubic solid solution (ss) $\mathrm{Fe}$ and $\mathrm{LiFeO}_{2}$ is formed. However $\mathrm{FeO}$ is stable only above $570{ }^{\circ} \mathrm{C}$, therefore $\mathrm{FeO}$ may decompose to $\mathrm{Fe}_{3} \mathrm{O}_{4}$ and, apparently $\mathrm{Fe}_{2} \mathrm{O}_{3}$ at temperatures lower than $570{ }^{\circ} \mathrm{C}$ as :

$$
\begin{aligned}
3 \mathrm{FeO}+\mathrm{O}^{2-} & =\mathrm{Fe}_{3} \mathrm{O}_{4}+2 \mathrm{e} \\
3 \mathrm{Fe}_{3} \mathrm{O}_{4}+\mathrm{O}^{2-} & =2 \mathrm{Fe}_{2} \mathrm{O}_{3}+2 \mathrm{e}
\end{aligned}
$$


The possible cathodic reactions in molten carbonate may be:

and /or

$$
\begin{array}{ccc}
3 \mathrm{CO}_{2}+4 \mathrm{e} & \rightarrow & \mathrm{C}+2 \mathrm{CO}_{3}^{2-} \\
\mathrm{CO}_{3}^{2-}+4 \mathrm{e} & \rightarrow & \mathrm{C}+3 \mathrm{O}^{2-}
\end{array}
$$

$$
\begin{array}{rll}
\mathrm{CO}_{2}+2 \mathrm{e} & \rightarrow & \mathrm{CO}+\mathrm{CO}_{3}^{2-} \\
\mathrm{CO}_{3}^{2-}+2 \mathrm{e} & \rightarrow & \mathrm{CO}+2 \mathrm{O}^{2-}
\end{array}
$$

As above mentioned and according to the postulate of the electrochemical theory, the anodic process may be the metal dissolution and / or anodic barrier formation. Barrier layer may by formed by dissolution-precipitation mechanism and / or solid state mechanism.

Also, the formation of $\mathrm{LiFe}_{5} \mathrm{O}_{8}$ and $\alpha-\mathrm{Fe}_{2} \mathrm{O}_{3}$ may occur according to the reactions [9]:

$$
\begin{gathered}
\mathrm{LiFeO}_{2}+4 \mathrm{Fe}+6 \mathrm{CO}_{3}^{2-} \rightarrow \mathrm{LiFe}_{5} \mathrm{O}_{8}+6 \mathrm{CO}_{2}+12 \mathrm{e} \\
2 \mathrm{Fe}+3 \mathrm{O}^{2-} \rightarrow \mathrm{Fe}_{2} \mathrm{O}_{3}+6 \mathrm{e}
\end{gathered}
$$

The stainless steel alloys $(2,3)$ containing $\mathrm{Ni}$ are characterized by the formation of $\mathrm{NiO}$ according to the reaction:

$$
\mathrm{Ni}+\mathrm{CO}_{3}^{2-} \rightarrow \mathrm{NiO}+\mathrm{CO}_{2}+2 \mathrm{e}
$$

From the above mentioned results and discussion it was indicated that the susceptibility of the investigated alloys $(1,2,3)$ to pitting corrosion in $\mathrm{NaCl}$ solution greatly depends on their chemical composition and conditions of their surface treatment. The increase of chromium content of the alloy and the presence of nickel in the alloy increase the resistance of the alloy to pitting corrosion. This may be due to the presence of higher content of chromium oxide in the surface film. Also, the preoxidation of the alloys in different media offers good resistance of their surface to pitting corrosion. It seems that the composition of oxide film formed on the alloys surface greatly depends on the preoxidation medium and its temperature. For this reason the resistance of the alloys $(1,2,3)$ greatly depends on the conditions of the preoxidation of their surface.

\section{Conclusions}

1 -The resistance of the alloy to pitting corrosion in $\mathrm{NaCl}$ solution greatly depends on its chemical composition. This resistance increases with the increase of the chromium content of the alloy and the presence of nickel.

2- The preoxidation of the alloys in different media greatly improves the resistance of the alloys to pitting corrosion. 
3- Preoxidation of the alloys in each of molten alkali nitrates and molten alkali carbonates overs more resistance to pitting corrosion than preoxidation in air.

\section{References}

1. G. Bianchi, A. Cerquetti, F. Mazza, S.Torchio, Corros. Sci. 12 (1972) 495.

2. J.R. Kearns, Proc. Conf. Corrosion 84, New Orleans, LA, USA, April 1984, NACE, 50.

3. J.R. Rastogi, B.K. Shah, A.K. Sinha, P.G. Kulkarni, Brit. Corros. J. 29 (1994) 78.

4. $\quad$ P.J. Gellings, M.A. De Jongh, Corros. Sci. 7 (1967) 413.

5. A. Baraka, A.M.S. Baraka, J. Appl. Electrochem.14 (1984) 305.

6. H.A. Abdel-Hakim, A.A. Attia, A.N. Al-Masri A.M. Baraka, AntiCorrosion Methods and Materials 48 (2001) 99.

7. A.A. Attia, Electrochim. Acta 47 (2002) 1241.

8. S.A. Salih, A.N. El-Masri, A.M. Baraka, J. Mater. Sci. 36 (2001) 2547.

9. A.A. Attia, S.A. Salih, A.M. Baraka, Electrochim. Acta 48 (2002) 113.

10. S.A. Salih, A.A. Attia, S.A. Abdel-Gawad, Egypt J. Chem. 47 (2004) 525.

11. N. Ramasubramanian, J. Electrochim. Soc. 127 (1980) 2566.

12. S.L. Marchiano, A.J. Arvia, Electrochim. Acta 17 (1972) 25 and 861.

13. A.A. Attia, A. Ali, A.N.A. Masri, A.M. Baraka, Mat.-wissu. Werkstofftech. 30 (1999) 1.

14. J.P.T. Vossen, A.H.H. Janseen, J.H.W. De Wit, J. Electrochem. Soc. 143 (1996) 58.

15. J.P.T. Voseen, R.C. Makkus, J.H.W. De Wit, J. Electrochem. Soc. 143 (1996) 66. 